\title{
Making a positive internet through Socmed Agawe Guyub
}

\author{
Fitrah Fasyanabilla Lotan, ${ }^{\text {a1,*, }}$ \\ a Ahmad Dahlan's Students Association of Communication Science, Jl Ki Ageng Pamenahan no 19, Yogyakarta 55164, Indonesia \\ ${ }^{1}$ fasyalotan@gmail.com*; \\ * corresponding author
}

\section{ARTICLE INFO}

Article history

Received 2019-05-11

Revised 2019-05-23

Accepted 2019-05-28

Keywords

Social Media

Internet Positive

Good Information

Yogyakarta

\section{ABSTRACT}

This peper aims to find out the efforts of the Yogyakarta government to teach internet positive to all citizens. The methodology of this study uses descriptive qualitative methods with a case study approach, this research uses analysis of literature and media. Media literacy is the answer to problems and concerns about provocative and negative information or messages that are now circulating among the public. Technological progress certainly does not always have a positive effect on society. Socmed agawe guyub become primer program for indonesians specially Yogyakarta can be more active to selected the infornation in social media and share only a good and right information in their social media.

This is an open access article under the CC-BY-SA license.

\section{Introduction}

Today, humans have experienced changes in terms of communication. Changes in the way of communication is influenced by the rapid advances in technology in this era of modernization. After the development of the internet, commonly referred to as New Wave Media or New Media, it is a beginning of the birth of changes in human communication today. The Internet creates a way of communicating using Social Media, it is not surprising that currently Social Media is becoming a new lifestyle among Indonesians, it can be seen from Fig. 1 which is shown an increasing social media users in Indonesia by the Association of Indonesian Internet Service Providers (APJII).

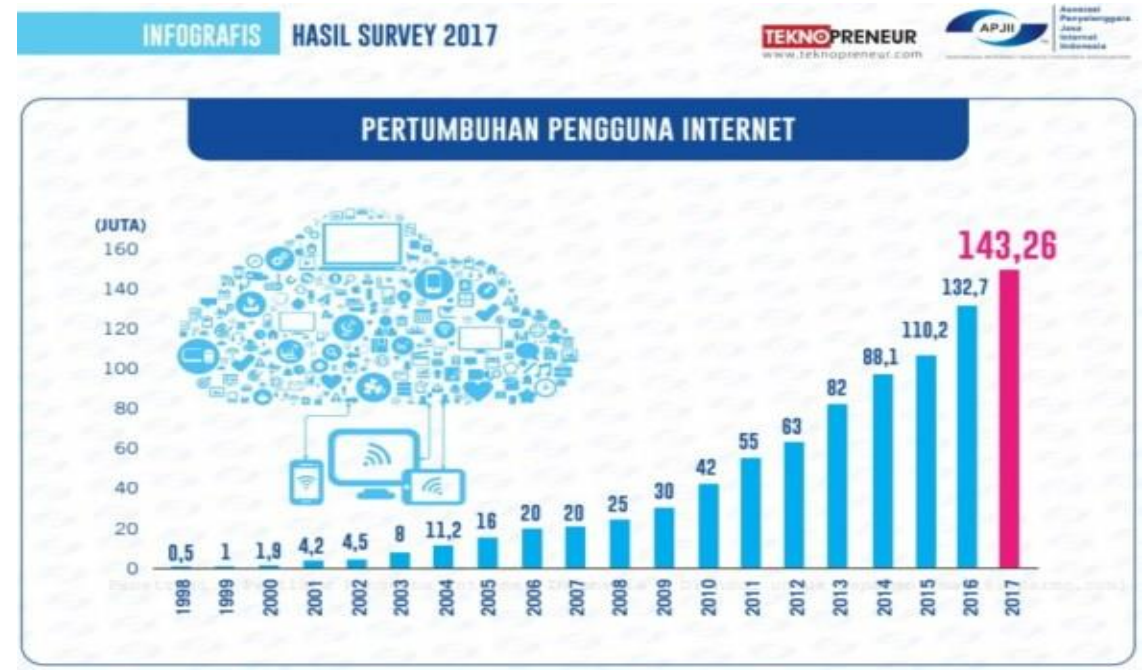

Fig. 1. The Graph of increasing social media users in Indonesia [1] 
From the graph we can see how the number of social media users in Indonesia is increasing every year. A very significant increase was seen in 2015 as many as 139 million social media users where there were an increase of 32 million users of social media compared to the year.

Previously, in 2014 there were 107 million users. This happens because of the renewal and improvement of applications every year, also coupled with social media trends that make people interested in using social media. There are a lot of social media in the midst of society today. Such as ; Facebook, Twitter, Instagram and Snapchat. The facilities obtained from each of these Social Media also have some similarities, among others, the facility of uploading photos, videos and audio, then text or chat. Some social media now also complete the application with the free video call feature. There are many new features that are always updated by the application. Unfortunately, the progress of social media technology is also like a double-edged knife. If we cannot sort out the information contained in social media, then we will become a passive society and tend to be influenced by negative content that is on social media. Freedom in the dissemination of information on social media creates information - negative information and even content that smells SARA and that information can be freely uploaded by users of social media. No doubt, some parties make this condition a tool to divide the nation or even poison the minds of the younger generation [2].

The impact of this is that the emergence of concerns about the people who cannot filter the information contained in social media makes some circles make several concepts to educate the Indonesian public about media literacy. Media literacy is important in this era of globalization. When freedom of information is very broad, anyone can access it and lack of filtering information provided by the server, the community must be able to sort out the information available. Some groups such as the government and other institutions that are concerned about media literacy in the Indonesian society are expected to be able to work together to create a media literacy program or movement, especially in social media to the community, which is expected from the movement or program will make people more aware of the importance of media literacy.

\section{Theoretical Framework}

\subsection{Concept of Information}

In this globalization era, people not only receive information from one source but more than tens of sources, even hundreds of sources that can contain information. Information released can be spread in seconds. All sources of information compete - being the first to spread the information. According to Livingstone today [3], the advancement of information technology that leads towards globalization of communication is felt to tend to have a direct effect on the level of civilization of society and nation. We are all aware that the development of information technology has been moving very rapidly lately and has caused positive and negative impacts on the governance of people's lives in various countries. Progress in the field of information takes us into the century of communication revolution. Some even call it a "Communication Explosion" Subrata, 1992. According to Amandha [4] If globalization is defined as the development of human culture, then the globalization of information and communication that arises due to the development of communication technology, is interpreted as electronic technology that can accelerate and improve the quality of information this is no longer limited by space and time.

Social media is a form of technological progress. Social media is becoming a medium in the dissemination of messages which in this case can be called a media for disseminating information to the public. Social Media according to Phillip Kotler and Kevin Keller [5] Social Media is a means for consumers to share text, image, audio and video information with each other and with companies and vice versa. According to Watsona [6] Social Media is a site.

Social networks are like web-based services that allow individuals to build public or semi-public profiles in a restricted system, list other users with whom they are connected, and view and explore lists of their connections made by others in a system. Meanwhile, Kaplan and Haenlein [7] define social media as "a group of internet-based applications that build on the basis of ideology and Web 2.0 technology, and which enable the creation and exchange of user-generated content. 
From the three definitions, it can be concluded that Social Media is a means of exchanging information between individuals based on an internet system to facilitate communication between individuals. Can also be used as a means of sales promotion or political communication.

Along with its development, online service providers make various advances, one of which is to add existing social media. These innovations are made not without reason but because of the many people who have become users and access social media. Fig. 2 shows the types of social media that are most widely used by the community.

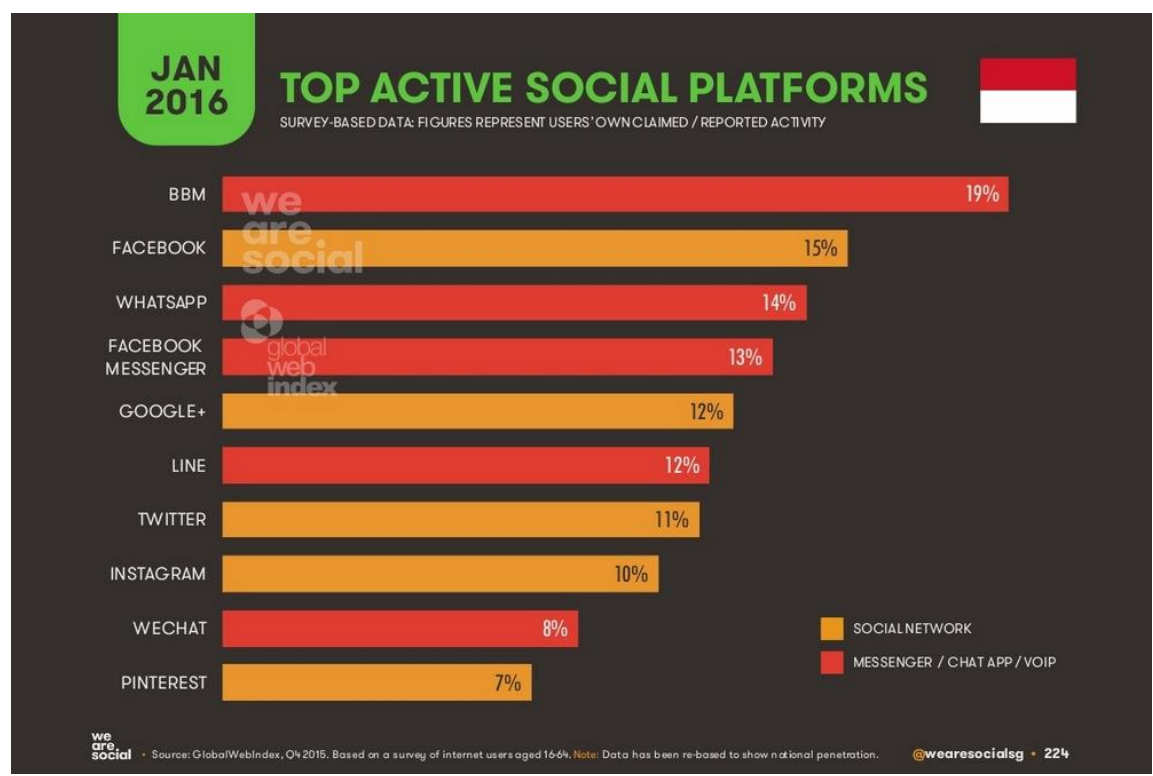

Fig. 2. Top Active Social Platforms [8]

Judging from the data taken in January 2016 it shows that the most widely used social media by the people of Indonesia is BBM and Facebook. bbm (blackberry messenger) is a social media application that was initially only available on blackberry mobile phones, however, along with the development of technology and the emergence of android mobile phones that dominate the technology market, fuel applications can be uploaded on android mobile phones. The second is Facebook. This social media at the beginning of its appearance has stolen many hearts of the world community. Facebook was created by a student who graduated from Harvard University, Mark Zuckernberg and some of his friends in February 2004. Initially Facebook was created for the communication needs of Harvard students only.

Along with the development of users, in 2009 Facebook was launched for the International realm. With features such as storing photos, videos where the public can easily provide information in the profile box that makes the public able to show their existence. Features on Facebook also continued to progress which eventually grew sales accounts online and several other accounts. This also makes Facebook a social media application that creates a new lifestyle in the community [9].

\subsection{Social Media become modern lifestyle}

Lay people in rural areas consider that they do not need social media. And social media is not too influential in their daily lives. Even those who are used to living without the influence of electronics or other media. That is what makes people in rural areas not make social media their lifestyle. As with the people who live in urban areas, social media is a medium for them to get the latest information or news because they can easily exchange information with social media on their mobile phones or in their electronic devices. In addition to a medium for getting and exchanging information, social media is also useful for them to take a break from their work routine. Social media is one of the practical entertainment tools and media that they can use in their leisure time before working, taking a break from work or when going home from work. Social media users are diverse and not age dependent [10]. However, the majority of social media users are young people. 
The youth with their curious character and finding out all information makes young people become active users of social media. Social media with its influence on society can create changes in behavior and even people's lifestyles. These changes can lead to positive changes or lead to negative changes. The influence of the media is related to other aspects such as the nature of the communicator, the content / information of the media itself, and responses from the community [11].

Lifestyle according to Kotler [5] is a person's lifestyle in the world which is expressed in his activities, interests and opinions. Lifestyle describes "the whole person" in interacting with their environment. Lifestyle describes the whole pattern of a person in action and interaction in the world. In general, it can be interpreted as a lifestyle that is recognized by how people spend their time (activities), what is important for people to consider in the environment (interests), and what people think about themselves and those around (opinion). Lifestyle is the behavior of a person who is shown in activities, interests and opinions, especially those related to self-image to reflect his social status.

lifestyle is an individual's way of life which is identified by how people spend their time (activities), what they consider important in their lives (interests) and what they think about the world around them. lifestyle is a combination of self-expression needs and group expectations of someone in acting based on applicable norms. Because of that, in this technological era the lifestyles that develop in society become various kinds. For example the hedonist lifestyle, metropolis lifestyle, global lifestyle, study and so on [12][2].

According to this theory there are new trends in the formation of one's character through the learning process. The difference in mindset and motivation is based on learning experience. Individual differences are caused by differences in the environment that result in differences of views in dealing with something. The environment will influence attitudes, values and beliefs that underlie their personalities in responding to the information that comes. Thus the influence of the media on individuals will vary from one another.

\section{Method}

The methodology of this study uses descriptive qualitative methods with a case study approach. this research uses analysis of literature and media. Strauss and Corbin [13], explained that qualitative research is a type of research whose findings should not be through statistical procedures or other forms of calculation. Research using case studies is research that focuses on one particular object and studies it as a case. data is collected through various sources [14]. Qualitative research requires a sharp and in-depth analysis of various factors associated with the case so that in the end an accurate conclusion will be obtained [15]. The purpose of this descriptive study with a qualitative approach is to explain the phenomenon deeply, through collecting data and using case study methods. The research flow is done by conducting literature research both online and offline. Then analysis of communication theories related to the case.

\section{Results and Discussion}

\subsection{The Socmed Agawe Guyub}

Currently we are all connected in a new public space called the Internet, in this public space everyone is interconnected without privacy, from Facebook to Google + all of which is a hammer that destroys the privacy wall among us. Social media account that we have a wide range of photos and activities Day day we can be easily accessed by anyone who can surf the virtual world, up to this point then we should all be aware that now privacy is an illusion [16].

The Socmed Agawe Guyub program is a program initiated by the Yogyakarta Special Region of Communication and Information (Diskominfo DIY) on 12 November 2016 in collaboration with the Kedaulatan Rakyat newspaper. This program educates the public to carry out media literacy in this era of globalization. This program initiated the principle of positive social media. This program is motivated by concerns about the community which can be divided by issues and even content negative content that tends to smell SARA even provokes Indonesian people. With this program, it 
is expected that the community can create a positive social media climate so as to create a harmonious society.

With this program, it is expected to prevent negative content through government cooperation with cyberspace activists. Diskominfo DIY informs the latest information system of Yogyakarta, namely Jogja Istimewa TV and Jogja Istimewa application for smartphone users. JITV Studio and the Provincial Government are open to people who want to share positive content in the form of videos. Special Jogja application is an application that has features including; tourism, culture, community services, events, transportation, health, augmented reality and access to public CCTV to monitor Jogja traffic.

Jogja is seen as a creative city. Almost every activity or event held in Jogja can attract the attention of people in other areas. Not surprisingly, many media cover all forms of events or activities in Jogjakarta, on that basis the government hopes that the Peace Journalism program inSocmed Agawe Guyub can affect Indonesian society. Making social media a medium for exchanging positive information away from the elements of provocation and so on. Making Indonesian people not only as passive social media users, but also more active in sorting and disseminating information [17].

The proliferation of social media in the community and the increasing number of social media users in Indonesia have led to the emergence of other benefits of social media. Beginning with the emergence of online accounts that sell goods that are needed by the community until social media develops into a medium of political communication in Indonesia. The use of social media as one of the political communication strategies used by several political figures in the world even in Indonesia [18]. During the 2008 Obama campaign in America. One of the factors that made Obama's popularity rise rapidly was because he was a candidate connected with potential voters through social media. In the 2008 US presidential election, Obama's campaign team used social media very effectively. Obama campaigned through several friendship sites such as Myspace, Twitter, Facebook, etc [19][20]. Thus, it is unsurprising that a common theme has emerged in the U.S. press, expressed succinctly by the Hudngton Post in the weeks after the 2008 presidential election: I were it not for the internet, Barack Obama would not be president.

In 2008 Obama gained a majority vote in elections by maximizing social media presence on Facebook and Twitter. Saw the success of the efforts of the candidates who Laain tried to emulate the same strategy. The phenomenon tells us that today is the time when social media becomes an important part of the political campaign. Candidates only need to follow some basic rules for playing social media to avoid misdisplaying content, which could compromise its popularity [21].

Social Media such as Facebook and Twitter enable people to be communed and iterating and discussing things politically even if they are not politicians. Recorded in the United States Barrack Obama became the first presidential candidate to utilize the social media platform as a means of campaign, recorded on November 4, 2008 Obama has 3 million fans on Facebook Berkai more folding than the Owned by John McCain as his rival. Even during his political campaign in 2008 he always had it live through YouTube and was watched by 14 million spectators. It all gets it at a very low cost utilizing social media. Social media has made it easy for political candidates to introduce themselves to the community, and the community is facilitated to provide support through social media, this is a real form of participation [22].

The internet has the potential to build a good image in politics because it is not one-way but it allows candidates and communities to interact directly. Ideally with this internet people from various corners can collect information as much as it can be well-taught and literated before dropping political choices, although not infrequently there are times when content is received By the public without a filter. But the point with the Internet of society can supervise the government on, can also check the claims of the candidates directly and explain the personal opinion on many people with an inexpensive cost [23].

The massive use of social media include facebook and Twitter has changed the culture of public communication with state officials who have been awakened so far. Social media presence makes public officials more to be cautious in taking action because all their policies are supervised by the public and the Meereka should be able to account for it. Because images of videos that are spread 
can directly reach the community in real time, the officials should also be more cautious in acting and spreading the content [24].

Since the middle of the 20th century Advertising firm always became the main tool of the American political campaign, the advertising company continues to fly there along with the development of survey institutions and public relations companies to prepare candidates when they must appear in Television or radio. With the development of digital technology the candidates then changed drastically their strategy to mobilize the masses and the participation of voters, especially young people to raise funds and provide the support of the volunteers in the level Grassroots. In the Amreika itself, the two major parties are the Democrats and the Second Republic both have a modern and sophisticated IT team [25]. Apart from the various political affiliations that won in the last elections in America, but the elections featured a variety of interesting phenomena [26].

These changes did bring up some effects. Some argue that the presence of political parties to raise the image of the politician Menjadikurang important because the Politi can greet its supporters and other audiences directly and with a very cheap funds, used to be able to greet Political party audiences that facilitate the politicians who want to be raised the image, but all have changed. The internet can also shake the status quo of well-established politicians because the Bisasaja audience is looking for other candidates who are not honored by the political party of the deprecating because it feels more resemblance and similarity to the vision of the audience. Point is a variety of alternative political pathways can be more open and not unexpectedly because anyone can do mass mobilization easily cheap and fast on the Internet for his political interests.

While the political campaign using social media in Indonesia began when the election of the Governor and Deputy Governor of DKI Jakarta. At that time the pair Joko Widodo (Jokowi) and Basuki Tjahaya Purnama (Ahok) in their campaign strategy used social media as a tool to communicate and communicate their ideas to the public. Both of these couples use social media accounts The unique campaign strategy carried out by the pair is a new strategy in the world of Indonesian politics. The movement carried out by Jokowi was very neat, professional and organized, starting with placing himself on social media in the same way as the real figure in the field. With an account @ jokowi_do2 (twitter), language and polite words "What I'm working on is just what I should have done ... It's normal, there's nothing special" one of the tweets Jokowi displayed. The right political communication strategy in the media [27].

Media choices that can meet their needs [28]. In this theory, individuals use media driven by the existence of needs and goals determined by the individual himself. In other words, the public is required to be more active in choosing the media to be accessed. So, it is expected that the community will be literated by itself. In an effort to create a well-literated society, the government certainly took part in realizing this. Socmed Agawe Guyub is a program that invites Jogjakarta people in particular to create smart communities in social media. It is hoped that this movement will be able to spread to all regions in Indonesia [20].

Based on the observations and discussions that have been made, the authors want to submit suggestions as follows: This writing only focuses on how to create a positive climate in using social media so that it reduces information or messages that are provocative to the Indonesian people, one of which is the Socmed Agawe Guyub program initiated by the Yogyakarta Communication and Information Agency (Diskominfo). The author suggests researching the effects of provocative messages spread on social media in the community and also examines the extent of the effectiveness of the Socmed Agawe Guyub program. These suggestions are made so that the knowledge of communication and media literacy can be richer and more diverse [29].

\section{Conclusion}

Media literacy is the answer to problems and concerns about provocative and negative information or messages that are now circulating among the public. Technological progress certainly does not always have a positive effect on society. The more free information circulating in the community increasingly raises the number of sources of information which is not necessarily the truth. Today, the era of globalization makes anyone able to become a communicator and social media as a medium to convey his message and the general public who will become his communicant. As McLuhan said [28] states that "media is a message". According to McLuhan, in 
using media people tend to emphasize the content of their messages only and people often do not realize that the media that delivers the message also affects their lives. The media forms and influences the message or information conveyed. Therefore, the stronger the influence of the media, especially at this time is social media, it is necessary to have control carried out by the community in order to be able to filter all existing information.

Media literacy is the ability to understand, analyze, and deconstruct media imagery. The ability to do this is so that viewers as media consumers (including children) become aware of how the media is constructed and accessed [30]. Theories related to media literacy are theories of use and satisfaction (Uses \& Gratification) [31]. The use theory and satisfaction focus attention on audiences as mass media consumers, and not on the message delivered. This theory assesses that audiences in using media are goal oriented, active and discriminatory at the same time. Assessments were assessed knowing their needs and knowing and being responsible for them.

\section{References}

[1] "Hasil Survei Penetrasi dan Perilaku Pengguna Internet Indonesia 2017," APJII, 2017. [Online]. Available: https://apjii.or.id/content/utama/39.

[2] Y. G. SAHIN, "THE USE OF INTERNET RESOURCES BY UNIVERSITY STUDENTS DURING THEIR COURSE PROJECTS ELICITATION: A CASE STUDY," Turkish Online J. Educ. Technol., vol. 9, no. 2, pp. 234-244, 2010.

[3] S. Livingstone, "The changing nature and uses of media literacy," 2009.

[4] Amandha Rohr Lopes, "The Impact of Social Media on Social Movements: The New Opportunity and Mobilizing Structure," J. Polit. Res., vol. 4, no. 1, pp. 1-23, 2014.

[5] K. Kotler, Phillip., Keller, Marketing Management. New Jersey: Pearson Education, Inc, 2012.

[6] W. T. Watsona, "Digital Media and Society Implications in a Hyperconnected Era," 2016.

[7] A. M. . M. H. Kaplan, Users of the world, unite! The challenges and opportunities of Social Media. Business Horizons, 2010.

[8] "Pengguna Internet Indonesia Nomor Enam Dunia," Kominfo, 2017. [Online]. Available: https://kominfo.go.id/content/detail/4286/pengguna-internet-indonesia-nomor-enamdunia/0/sorotan_media.

[9] C. Fuchs, Social Media a Critical Introduction. Los Angeles: Sage Publication, 2014.

[10] D. F. Mariana Ulfah, Choirul Fajri, "PEMAHAMAN LITERASI MEDIA DI LINGKUNGAN PENGURUS PIMPINAN WILAYAH AISYIYAH DAERAH ISTIMEWA YOGYAKARTA PERIODE 2015-2020," Informasi, vol. 47, no. 2, 2017.

[11] John A. Bargh and Katelyn Y.A. McKenna, "THE INTERNET AND SOCIAL LIFE," Annu. Rev. Psychol, 2004.

[12] Alvin C. Burns and Mary Carolyn Harrison, "A Test of the Reliability of Psychographics," J. Mark. Res., vol. 16, no. 1, pp. 32-38, 1979.

[13] C. J. A, Strauss, Dasar-Dasar Penelitian Kualitatif: Tatalangkah dan Teknik-teknik Teorisasi Data. Yogyakarta: Pustaka Pelajar, 2003.

[14] N. Hadari, Metode Penelitian Bidang Sosial. Yogyakarta: Gajah Mada University Press, 2003.

[15] J. L. Moleong, Metodologi Penelitian Kualitatif. Bandung: Remaja Karya, 2002.

[16] Pooja Kashyap, "Badmouthing Employers On Social Media: A Sign Of Harmony Imbalancement In Life," Thinking Turf, 2019. [Online]. Available: http://www.techietonics.com/thinkingturf/badmouthing-employers-on-social-media-a-sign-of-harmony-imbalancement-in-life.html.

[17] G. Kress, Literacy in the New Media Age (review), vol. 82, no. 4. 2006.

[18] Valentino Larcinesey \& Luke Miner, "The Political Impact of the Internet in US Presidential Elections," Department of Government, London School of Economics, 2017. [Online]. Available: http://sticerd.lse.ac.uk/dps/eopp/eopp63.pdf. 
[19] Nicholas Thompson, “The Internet and Political Campaigns," The Globalist, 2003. [Online]. Available: https://www.theglobalist.com/the-internet-and-political-campaigns/.

[20] E. Murwani, "The Impression Management Strategy of the Candidates of Governor-Vice Governor of DKI Jakarta on Social Media," vol. 03, no. April 2017, 2018.

[21] Joanna, "The Three Golden Rules Of Social Media In Political Campaigns," Financial Industry Regulatory Authority, 2019. [Online]. Available: https://www.workfront.com/blog/the-three-goldenrules-of-social-media-in-political-campaigns.

[22] Caitlin Chin, "Social Media and Political Campaign," GEORGETOWN PUBLIC POLICY REVIEW, 2019. [Online]. Available: http://www.gpprspring.com/social-media-political-campaigns\#test-copy-ofretweets-hashtags-and-political-campaigns.

[23] P. Williams, "How the Internet is Being Used by Political Organisations: Promises, Problems and Pointers," 1998.

[24] T. Murse, "How Social Media Has Changed Politics," ThoughCo, 2019. [Online]. Available: https://www.thoughtco.com/how-social-media-has-changed-politics-3367534.

[25] J. Chester, "The role of digital marketing in political campaigns," Cent. Digit. Democr., vol. 6, no. 4, 2017.

[26] H. Mazouri, "Social media guide for political campaigns," SproutSocial, 2018. [Online]. Available: https://sproutsocial.com/insights/social-media-for-political-campaigns/.

[27] S. Media, "Social Media and the Political Campaign Industry in Indonesia," vol. 03, no. 01, 2018.

[28] Morissan, Teori Komunikasi individu hingga massa, . Jakarta: Kencana Prenamedia Group, 2013.

[29] “2003 [Anna_Everett,_John_Caldwell]_New_Media_Theories_(BookFi.org).pdf.”.

[30] L. Lessig, Free Culture: How Big Media Uses Technology and the Law to Lock Down Culture and Control Creativity. Yogyakarta: KUNCI Cultural Studies Center, 2011.

[31] R. Nasrullah, Komunikasi Antar Budaya di Era Budaya Siber. Jakarta: Prenada Media, 2012. 